\title{
Review of energy recovery from construction and demolition waste in Australia
}

\author{
S. Shooshtarian*, T. Maqsood, P.S.P. Wong, M. Khalfan, R.J. Yang \\ RMIT University, School of Property, Construction and Project Management, Melbourne, Australia
}

\begin{abstract}
The construction industry in Australia has grown significantly in the past two decades in the wake of population growth, migration and expansion in the tertiary education industry. The growing population has necessitated extensive property development, better public transport and improved infrastructure. To achieve all of this, construction activities have been on rise; resulting in a significant growth in construction and demolition (C\&D) waste generation. Australia has adopted a waste hierarchy to manage waste including $\mathrm{C} \& \mathrm{D}$ waste. According to this notion, waste produced should be managed in a hierarchal order comprising reduction, re-using, recycling, energy recovering, treatment and disposal. Energy recovery of waste is a new concept to the Australian context where, due to a lack of regulatory support and environmental concerns, it has not been well-developed. This review study aims to provide insight into Energy from Waste (EfW) activities in Australia at both national and jurisdictional levels. It reviews associated regulations and standards to show how EfW is being perceived and practiced. The findings demonstrate that Australia has a long way to go to fully utilise EfW opportunities, the role of government in providing regulatory support to promote EfW is found to be of particular importance. Furthermore, several measures are recommended to navigate efforts leading to improved $C \& D$ energy recovery activities in Australia. The results are expected to be beneficial to the $\mathrm{C} \& \mathrm{D}$ waste industry, researchers and regulatory authorities in the development of useful regulations and best management practices.
\end{abstract}

\section{Keywords}

Population growth; Regulatory framework; Waste hierarchy; Construction and demolition; Energy from waste; Energy recovery

Received: 21 June 2019; Accepted: 02 September 2019

ISSN: 2630-5771 (online) C 2019 Golden Light Publishing All rights reserved.

\section{Introduction}

The construction industry in Australia has grown significantly in the past two decades in the wake of population growth, migration and expansion in the tertiary education industry. The growing population has necessitated extensive property development, better public transport and improved infrastructure. The range of construction activities initiated in response involve businesses that are involved in

\footnotetext{
Corresponding author

Email: salman.shooshtarian@rmit.edu.au
}

creating residential and non-residential buildings (including renovations and additions), engineering structures, and associated trades and services [1]. The industry is identified as the fourth largest contributor to growth domestic product (GDP) [2]; more than 1 million people work in the industry. Unsurprisingly, this volume of construction brings about a huge volume of waste, known in the industry as "construction and demolition (C\&D) waste”. In 2016-17, approximately 20.4 Mt of C\&D 
waste was produced in the Australian construction industry, which accounts for $38 \%$ of the total core waste (Solid non-hazardous waste and hazardous waste including liquids, and generated in the municipal, $\mathrm{C} \& \mathrm{D}$ and Commercial and Industrial (C\&I) sectors, generally excluding primary production.) generated in Australia [3].

Due to its substantial impact on the economy, society and the environment, generation of $C \& D$ waste has been a source of concern for Australians for many years $[4,5]$. This has resulted in state governments paying more attention to this growing issue. For instance, in the late 1990s, the citizens of Canberra demanded the state government consider a "no waste policy" to manage C\&D waste. In 1996, this demand resulted in the implementation of the first zero waste strategy of its kind for a city [6]. Due to improvements in public awareness about the environment, Australian state governments have become increasingly pressured to tackle this issue. The community also expects construction companies to manage the waste they generate [7]. Consequently, more state governments have shown interest in launching a number of construction waste reduction projects and in facilitating multiple strategies to avoid, reduce, recycle and re-use C\&D waste $[8,9]$.

The primary framework underpinning waste strategies followed by Australian jurisdictions is the waste hierarchy. The waste hierarchy is a nationally and internationally accepted concept used to prioritise and guide efforts to manage waste. This framework, as shown in Fig. 1, has six levels of waste management. The least preferable option is waste disposal and the most desirable is to collectively avoid and reduce waste. The waste hierarchy also plays an important role in waste related acts and regulations by contributing to setting regulatory objectives that aim to achieve waste management goals. Some examples of its application include regulations and acts enforced in [10-16]. However, its application (e.g. the modification in the levels of hierarchy) differs greatly.

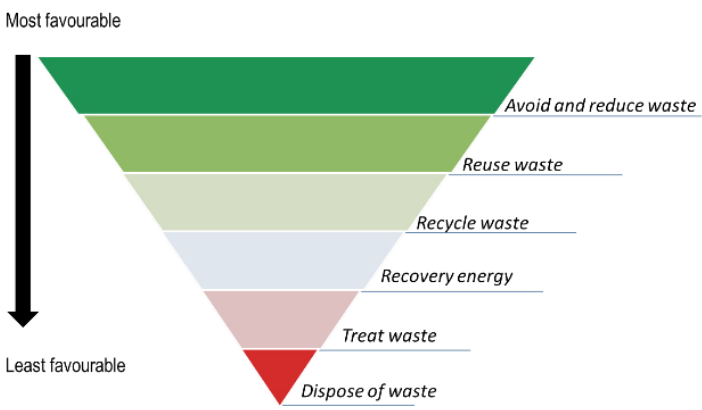

Fig. 1. Waste hierarchy adopted by waste strategy documents across Australia

The rate of Energy from Waste (EfW) among the other waste fates varies within different countries. The recent statistics for general waste, including the $\mathrm{C} \& \mathrm{D}$ stream, show that this method contributes to $26 \%$ of Denmark [17], $37 \%$ of Norway [18], $1 \%$ of the UK [19] and $4 \%$ of US [20] waste management practices.

In 2000, the Netherlands' C\&D activities generated 400,000 tons of wood, which was either landfilled or used to produce electricity [21]. In 2012 , it was reported that, in the Netherlands, only $2 \%$ of C\&D waste was energy recovered [22]. Recent European directives like 2008/98/EC and the future RED II for 2021-2030 have supported the application of new EfW solutions using modern technologies [23], such as gasification, that are more efficient environmentally and economically.

There are number of globally known issues that deter adoption of this waste management method. These include public resistance, the cost associated with the establishment of required facilities (e.g. capital and operational costs), the commitment to provide feedstock fulfilled by long term contract, diverting activities from recycling to energy recovery, feedstock scarcity in relation to $C \& D$ waste, air pollution and stench, and ongoing amenity issues.

One pressing issue about EfW uptake and development concerns social acceptance and community attitude towards EfW. The relevant literature label this issue the Not-in-My-Back -Yard (NIMBY) attitude syndrome [24]. In the past, there have been some instances of public resistance (protest) against establishment of EfW facilities 
[25-28]. However, the most recently published studies indicate a higher rate of social acceptance of EfW in countries such as China [29], Canada [30] Greece [31] and Australia [32]. The relatively lower rate of resistance against EfW in the more recent studies might be explained by improvements in EfW incinerator technologies [33] and raised public environmental awareness. Several research studies have conducted a social cost-benefit analysis of EfW compared to other waste management options [34-39] and demonstrate the social benefits of energy recovery.

In a study in China during 2016, it was found that a community's opinion about waste derived energy recovery in their neighbourhood proximity optimistic. The factors affecting risk perception were education level, previous experience of stench and gender. The interesting part of this study's results was related to the insignificant impact of distance to risk perception, implying the important role of knowledge and information about EfW and the notion that effective risk communication results in reduction of psychological resistance to EfW [29]. In addition, a different study provided the root causes of resistance against EfW, including stench and other air pollution [29], property value [26] and health issues [34, 40].

One of the barriers to expansion of waste incineration activities is related to EfW facility establishment cost implications. Projects involving EfW require significant capital investment and operating costs, which typically require investment contribution from governments. In terms of operational costs, some previous research studies demonstrated that EfW is more expensive than landfilling [34, 35, 41, 42] but can become more reasonable when social costs are accounted $[36,37$, 41] reported that the estimated cost of EfW is about $\$ 58$ per tonne in Boulder (US), which is higher than the typical landfill levy imposed across the US. Furthermore, through advances in technology used to recovery energy activities, there are opportunities to improve its efficiency and cost effectiveness. For instance, [43] reported that, with some technological modifications, compared to the current situation, the electricity produced in energy recovery facilities can be improved by $60 \%$ by 2030 in Malaysia.

In order to take advantage of the economy of scale, a long-term contract is required for sustainable operation of EfW facilities. These contracts are prevalent and guarantee waste supply to EfW facilities [35]. The long-term commitment to provide ongoing feedstock, however, gives raise to other issues, such as diversion from recycling activities that are more preferred options in the hierarchy of effective waste management [32].

The last known issue is the uncertainty about feasibility of continuous procurement of feedstock for EfW facilities for C\&D waste [44]. It will take several decades until a large quantity of construction materials come to their end of life status and become an input for EfW.

Waste recovery is the fourth most desirable option in the management of waste, according to the waste hierarchy. By definition, waste recovery is "to make use of a waste material, including recycling of waste matter and recovering energy or other resources from waste" [45]. Energy recovery is a valid pathway for residual waste in contexts in which further material recovery through other methods is not cost effective or technically practical, there is community acceptance of the processes involved in energy waste, a consistent supply of feedstock and the intended materials have a high calorific value. It has the potential to deliver renewable or low carbon energy in a cost-effective way.

The main technologies used to perform energy recovery are either based on thermal treatment or biological processing of biodegrade waste:

- Combustion that produces heat

- Gasification that produces a combustible syngas

- Pyrolysis that produces syngas, oil or char

- Anaerobic digestion/fermentation that produces biogas

- Mechanical sorting and processing that produces combustible refuse derived fuel (RDF)

The residual waste derived from mixed $C \& D$ waste recycling activities with a high timber and plastic content is suitable for energy recovery 
processes and this can provide a higher order use than landfill disposal of these materials, particularly where the waste material displaces the use of fossil fuels for energy generation [9]. For instance, $1 \mathrm{~kg}$ of wood can provide the same energy as $0.34 \mathrm{~kg}$ of standard coal; thus, one tonne of wood waste, when recovered, can replace the consumption of $343 \mathrm{~kg}$ of standard coal. C\&D waste residual is used in certain EfW technologies namely combustion, gasification and pyrolysis.

Energy recovery from waste and programs contribute to the development of a new market for C\&D waste [46]. This market development occurs in relation to the adoption of circular economy principles, in which there is a preference for renewable materials and energy [47], as opposed to the traditional (linear take-make-use-dispose) approach, in which there is a limited use of renewable materials and energy [48]. Circular economy advocates believe that waste (materials) should be recovered as high up the waste hierarchy as practical and, in this way embodied materials, energy and wastes are retained in the economy [49].

It is projected that, in future, the cost of landfilling activities will increase due to land scarcity and disamenity [36], government intervention through supporting energy recovery activities and an increase in landfill levies, thus making energy recovery from waste even more cost-effective. One good example of the impact of land scarcity on the choice of waste management is in Japan where more than $80 \%$ of its solid municipal waste was incinerated in 2014 [50].

In addition, although recycling continues to provide a more favoured waste management option, the inability to recover energy value can be a substantial concern related to this option. Therefore, the best management practices for EfW need to be sought so that it can contribute to waste management strategy as well as renewable energy and environmental policies. This review study has set the following objectives in order to shed light on the status of recovery energy from C\&D waste in Australia:

- To identify and compare the rate of different waste management options in Australia
- To explore the existing regulatory capacity to support energy recovery in Australian states and territories

- To examine different case studies that are involved in energy recovery activities

This work is a literature review that forms part of a larger project (A National Economic Approach to Improved Management of Construction and Demolition Waste), which is being conducted at RMIT University and is supported by the Australia Built Environment National Research Centre. This project endeavours to foster a holistic national approach to address C\&D waste issues. Its objectives include the development of a consistent approach to define and measure C\&D waste, identification of influential economic factors that govern management of $C \& D$ waste, completion of a feasibility study on the creation of a marketplace for trading C\&D waste and identification of opportunities to integrate supply chains model in management of $C \& D$ waste.

\section{Materials and methods}

\subsection{Data collection, processing and analysis}

This review study is based on the secondary data that are publicly available. The document analysis technique was conducted to identity differences in jurisdictional regulatory frameworks and practices in Australia. The sources reviewed include acts, policies, regulations and strategies that are mostly administrated by the Australia Environmental Protection Authority (EPA) and other state-specific authorities (e.g. Sustainability Victoria in Vic), plus reports and initiatives prepared for $C \& D$ waste management in Australia. In total, 70 documents that provided information about C\&D waste legislation in Australia were analysed. It is worth noting that amendments to $C \& D$ waste regulations and acts occur periodically; therefore, information provided in this paper is considered valid at the time of writing. On this basis, the regulations that are not in force and or have been repealed are excluded from the review. Descriptive analysis is used to analyse and present the data collected. Quantitative results are mostly presented using analytical 
measures such as frequency and arithmetic average. Microsoft Excel V. 2016 is used to analyse the data and visualise results.

\subsection{Context of study}

Australia is a large country with a low population and density. The majority of the population of 25 million is settled in capital cities. Significant growth in migration and population in Australia have generated demands for more construction activities. As a result, more infrastructure and new housing are needed to meet the requirements of this ever-increasing population [51]. A more detailed overview of the construction industry is provided in the results section. The statistics have shown that construction activities generate a large quantity of C\&D waste [3]. Despite having no physical shortage of landfill sites, there is a high level of community environmental awareness; this means that it is difficult to open new landfill sites and incineration is not tolerated [52]. As such, the state governments attempt to regulate $\mathrm{C} \& \mathrm{D}$ waste management through enforcing relevant legislation.

\section{Results and discussion}

\subsection{Overview of the Australian construction industry}

Construction in Australia comprises several activities; from general construction to the construction of pipelines, railroads and river works, it also involves irrigation projects, and the construction of water, gas, electricity and sewage infrastructure. According to Australian and New Zealand Standard Industrial Classification (ANZSIC), 2006 (Revision 2), the Construction industry (Division E) involves three subdivisions: "Building Construction", "Heavy and Civil Engineering Construction" and "Construction Services" [1]. Each of these subdivisions is further divided into various "groups" and "classes" with certain activity definitions. Although there has been a slight negative annual growth in this industry from 2014 to 2019 in general, it is projected that the construction industry will enjoy a $2.4 \%$ annual growth between 2019-2024 [51].
Analysis of different construction subdivisions reveals a constant annual growth rate. For instance, the historic data from the Australian Bureau of Statistics (ABS) indicated that the value of work done in building construction activities has progressively increased by $33 \%$ from 2012 $(22,099,416)$ to $2018(29,428,494)$. During this period, the Australian population has grown by $11 \%$ [53]. These two trends clearly demonstrate the industry's attempt to keep up with the growing population. In the residential sector, approximately 18,000 dwelling units were approved for construction monthly in 2017 [54]. In the Heavy and Civil Engineering Construction subdivision, the annual revenue was estimated to be $\$ 394.3 \mathrm{bn}$, which provided over 1 million jobs in Australia. Road and bridge construction was recorded to benefit a 5.3\% annual growth and $\$ 28.9$ bn revenue [51]. In the construction engineering sector, the annual value of work commenced (all subdivisions) had an average annual growth rate of $19.9 \%$ from 2015 to 2018 (June) [55]. This increase is reported to be significantly larger in some states such as Vic (up to $80 \%$ ) and WA (39\%).

\subsection{Energy recovery rate in Australia}

In the Australian regulatory and reporting context, resource recovery typically refers to all activities that maintain the value of waste, including reusing, recycling and energy recovery. However, this is not always the case; for instance, in New South Wales (NSW), the main environmental act separates energy recovery from resource recovery. Hence, confusion may be created when reporting energy recovery activities. Sometimes the quantities are reported for resource recovery, which includes recycling and energy recovery. Among the waste fates, energy recovery rate is estimated to be $4 \%$, preceding the recycling (58\%) and disposal (38\%) rates [3]. During the period 2006-07 to 2014-15, energy recovery also increased markedly from about $1.4 \mathrm{Mt}$ to $2.3 \mathrm{Mt}$, or an average of $6 \%$ per year. However, there appears to be a continuous decline in the growth rate. According to the last estimations, between 2016 and 2017, about 1.97 Mt of core waste underwent EfW processes, of which 
90\% was through landfill gas collection [3]. With the exception of Qld (3\%), the energy recovery rate in 2017 was $4 \%$ across all Australian states and territories. According to the latest statistics (20162017) published in NWR [3], the share of C\&D streams in the amount of energy recovery is negligible (2.3\%) compared to MSW (62.1\%) and C\&I (35.6\%) streams. The waste recovery rate (recycling+energy recovery) for C\&D waste material has grown by $7 \%$ from $60 \%$ in 2007 to 67\% in 2017.

\subsection{An overview of energy recovery activities in Australia}

\subsubsection{People's perception and support}

Studies that provide a clear picture of Australians' perceptions on EfW are limited. In 2012, Wainberg [52] claimed that incineration is not tolerated among the public due to their environmental concerns. The Australian Council of Recycling suggested that Australia has to take a cautious approach to EfW and pointed out that, while the industry is not advocating EfW, it believes it has a place [56]. The public concerns about the consequences of energy recovery facilities are detailed in some other documents [57, 58]. However, this perception is expected to gradually change in a few years; for instance, the findings of a feasibility study for EfW facility in Vic [32] portrayed a milder picture. The study showed that there is a broad but conditional support from the public for EfW as an alternative to landfilling in Melbourne. How the relevant technologies work, the risks involved in the project and how the hazardous output would be dealt with were the main concerns. Currently, a number of jurisdictions (e.g. Vic and ACT) have initiated community consultation for energy recovery. In 2018, EPA released the findings of a review of the literature on potential health effects in local communities associated with air emissions from EfW facilities [59]. The results are available to the public and may play an important role in social acceptance of EfW.

\subsubsection{Examples of energy recovery activities in different jurisdictions}

In Australia, the waste and resource recovery industry is slowly adopting new technologies to efficiently extract energy from waste. At the same time, the Australian government, together with state and territory governments, have recently realised the environmental, social and environmental benefits of EfW activities and begun to support, regulate and fund EfW activities. Several funding schemes have been announced to assist in the establishment of modern energy recovery facilities; the source of funding in some jurisdictions such as Qld and NSW is landfill levy revenue. Federal government also receives and funds large EfW plant proposals on a case-by-case basis.

Historically, the main approach to recovering energy from waste in Australia is to capture gas from landfills. Among the jurisdictions, Vic has the leading energy recovery system in Australia, with more than 23 active landfills. Two financial measures of EfW performance typically used to build a case for establishment of a new/upgrade EfW facility are 1) the capacity of power supply and 2) the number of jobs it would create during construction and operation. Table 1 shows some examples of EfW facilities and activities across Australia.

\subsubsection{Opportunities}

The main opportunities for EfW development are the products generated following EfW activities (i.e. electricity, heat and processed-engineered fuels), reduction in waste going to landfill, securing of some environmental benefits, including reduction of greenhouse gas emission, and job creation. In Australia, the waste and landfill services account for $2 \%$ of greenhouse gas emissions [68]. Submissions to the [56] from local governments advised that Energy from Waste can provide opportunities to assist with power supply, and create manufacturing and operation related jobs. For instance, in WA, it is projected that an EfW facility can create 800 jobs opportunities during construction and 60 full time jobs during operation. 
Table 1. Examples of EfW facilities in Australia

\begin{tabular}{|c|c|c|}
\hline & Status quo and future plans & C \& D waste \\
\hline $\mathrm{ACT}$ & $\begin{array}{l}\text { The only energy generated from waste is achieved through two close landfill } \\
\text { cells. A proposal was made to build a } 200 \text { million EfW facility that will } \\
\text { produce up to } 30 \text { megawatts of electricity [60]. It would also burn waste } \\
\text { shipped in from NSW through rail lines. }\end{array}$ & $\begin{array}{l}\text { ACT began thermal } \\
\text { processing of C \& D } \\
\text { waste (e.g. wood) in } \\
2015 .\end{array}$ \\
\hline NSW & $\begin{array}{l}\text { In } 2017 \text {, the federal government announced that, through the Clean Energy } \\
\text { Finance Corporation, it would lend } \$ 30 \text { million to ResourceCo to build two } \\
\text { EfW plants to transform non-recyclable waste into processed engineered fuel } \\
\text { [61]. }\end{array}$ & No known activities \\
\hline NT & $\begin{array}{l}\text { A landfill site (Shoal Bay Waste Management Facility,) commissioned in } \\
2005 \text {, can capture methane and produce } 789 \text { MWh, which can supply the } \\
\text { electricity demand of more than } 1000 \text { households [62]. }\end{array}$ & No known activities \\
\hline Qld & $\begin{array}{l}\text { In } 2018 \text {, a proposal put forward the construction of a } \$ 400 \text { million EfW facility } \\
\text { in Qld that can provide electricity for } 50,000 \text { households [63]. }\end{array}$ & No known activities \\
\hline SA & $\begin{array}{l}\text { The SITA-Resource Co facility at Wingfield is Australia's first Refuse Derived } \\
\text { Fuel (RDF) manufacturing plant in Australia. }\end{array}$ & $\begin{array}{l}\text { C\&D derived wood } \\
\text { waste is used by SITA- } \\
\text { Resource Co to produce } \\
\text { processed engineered } \\
\text { fuel }\end{array}$ \\
\hline Tas & $\begin{array}{l}\text { Some efforts were made to include waste wood in the Renewable Energy } \\
\text { Target for energy recovery and power supply across the state [64]. }\end{array}$ & $\begin{array}{l}\text { Wood waste is used to } \\
\text { help power a pulp mill }\end{array}$ \\
\hline Vic & $\begin{array}{l}\text { Landfill gas capture is a mature technology and is a common practice in } \\
\text { Victoria. In 2004, there were } 23 \text { landfill sites that capture methane. A plan for } \\
\text { building an energy recovery facility in Melbourne's west is being considered } \\
\text { by the EPA. It is anticipated that this plant could convert } 200 \mathrm{Kt} \text { of residual } \\
\text { waste to provide electricity for } 20,000 \text { houses. This state also provides funds } \\
\text { for WtE infrastructure establishment, with the target to generate } 8,003,422 \\
\text { kWh electricity [65]. }\end{array}$ & No known activities \\
\hline WA & $\begin{array}{l}\text { This state has an active plant for EfW (Richgro) from C \& I organic waste to } \\
\text { produce renewable energy and pewter that is exported back into the grid. This } \\
\text { facility was finicality supported by different authorities, including state and } \\
\text { commonwealth governments and the Clean Energy Finance Cooperation. The } \\
\text { state approved two EfW facilities for MSW in } 2015 \text {. Both are in the south of } \\
\text { the metropolitan area and in close proximity to Rockingham and Kwinana [66]. } \\
\text { The first Australian big EfW plant is scheduled to be built in Kwinana } \\
\text { Industrial Area around } 40 \mathrm{~km} \text { south of Perth that can convert up to } 400 \mathrm{Kt} \text { of } \\
\text { unrecyclable waste for generating power that is enough for 50,000 households } \\
\text { [67]. }\end{array}$ & No known activities \\
\hline
\end{tabular}

ACT: Australia Capital Territory, NSW: New South Wales, NT: Northern Territory, Qld: Queesland, SA: South Australia, Tas: Tasmania, Vic: Victoria, WA: Western Australia

According to projections stipulated in proposals for establishment of EfW facilities across Australia, they can supply power for between 1000 Northern Territory (NT) and 50,000 (Qld, WA) households.

\subsubsection{Industry perspective}

The waste and resource recovery industry in Australia is the frontline in energy recovery in Australia. They have the determining influence on EfW and need motivation to operate and develop their EfW activities. One feasibility study project in Australia reported that industry suggests that a minimum 20-year contract is required for expansion and sustainable operation of EfW facilities in Victoria [32]. They also advised that cost disparity between landfilling and energy recovery should be properly addressed. The other concern raised by the industry in a SA consulting study [69] is the need for the development of a domestic market for energy recovered from waste, 
particularly since China's National Sword Policy has been implemented whereby import of waste is banned. There is evidence for operation of this yet to be fully developed market in SA, NSW and Tas (Table 1). Regarding C\&D waste, the industry consultees of SA's study also raised the issue of uncertainty about on-going availability of feedstock due to the long lifecycle of construction materials.

\subsubsection{Australian government}

Environment and Communications References Committee [56] realised that regulatory and financial support from federal government is required to expand EfW activities. The lack of regulatory and financial support is mentioned in several other resources [32, 57]. On 27 April 2018, the Minister for the Environment and Energy announced that the Australian Government has tasked the Clean Energy Finance Corporation and the Australian Renewable Energy Agency prioritising EfW projects. By law, the Australian government is not directly involved in regulation of waste unless there is a threat to the environment that is of national concern [102]. If not managed properly, energy recovery can become an environmental issue of national concerns. Hence, Australia's government can and should take a more proactive role in governing EfW activities by setting a sound national policy. State governments then can adopt the national policy. Currently, there are a number of nationwide regulations that have relevance to EfW, its benefits and adverse effects. Table 2 summarises these acts and regulations.

On the other hand, there are some concerns that the federal government support should not aim to replace recycling with energy recovery and that recycling has to remain the main policy priority; if it does not take priority, the public will lose the community commitment to recycling [56].

Table 2. National regulatory framework with an indirect impact on energy recovery

\begin{tabular}{|c|c|}
\hline Piece of Legislation & Relevance to energy recovery \\
\hline $\begin{array}{l}\text { National Environment Protection } \\
\text { Council Act [70] (Cth) }\end{array}$ & $\begin{array}{l}\text { Outlines an agreed consistent national approach for protecting or managing } \\
\text { particular aspects of the environment. }\end{array}$ \\
\hline National Waste Policy [45] & $\begin{array}{l}\text { Provides direction for Australia to produce less waste for disposal and manage } \\
\text { waste as a resource to deliver economic, environmental and social benefits. }\end{array}$ \\
\hline $\begin{array}{l}\text { Renewable Energy (Electricity) } \\
\text { Act [71] (Cth) }\end{array}$ & $\begin{array}{l}\text { Provides a legislative basis for the uptake of renewable energy within Australia. } \\
\text { It does this by legislating for the recognition and accreditation of renewable } \\
\text { energy producers. It determines what is included in the definition of renewable } \\
\text { energy. }\end{array}$ \\
\hline $\begin{array}{l}\text { National Pollutant Inventory } \\
\text { (NPI) }\end{array}$ & $\begin{array}{l}\text { Provides information on the types and amounts of certain substances being } \\
\text { emitted to the environment. }\end{array}$ \\
\hline $\begin{array}{l}\text { The National Greenhouse and } \\
\text { Energy Reporting (Measurement) } \\
\text { Determination } 2008\end{array}$ & $\begin{array}{l}\text { Supports the aims of the Clean Energy Act } 2011 \text { and the National Greenhouse } \\
\text { and Energy Reporting Act } 2007 .\end{array}$ \\
\hline $\begin{array}{l}\text { National Environment Protection } \\
\text { (Ambient Air Quality) Measure } \\
{[72](\mathrm{Cth})}\end{array}$ & $\begin{array}{l}\text { Establishes 'monitoring investigation levels' for five specified air toxics. } \\
\text { Monitoring data gathered under the Air Toxics NEPM will inform future } \\
\text { decisions on the management of these pollutants. }\end{array}$ \\
\hline $\begin{array}{l}\text { Environment Protection (Air } \\
\text { Toxics) Measure [73] ( }\end{array}$ & $\begin{array}{l}\text { Sets national standards for the key air pollutants to which most Australians are } \\
\text { exposed. Under the Air NEPM, all Australians have the same level of air quality } \\
\text { protection. }\end{array}$ \\
\hline $\begin{array}{l}\text { Environment Protection and } \\
\text { Biodiversity Conservation Act } \\
\text { [74] (Cth) }\end{array}$ & $\begin{array}{l}\text { The Act is the primary Commonwealth legislation directed to protecting the } \\
\text { environment in relation to Commonwealth land and controlling significant } \\
\text { impacts on matters of national environmental significance. }\end{array}$ \\
\hline
\end{tabular}




\subsection{Jurisdictional regulatory framework to support EfW}

Most of the regulations in states and territories in Australia follow the waste hierarchy in which energy recovery is preferred over landfilling. Despite this theoretical regulatory support in legislation, there is a need to set sound and easy-tofollow policies that can boost EfW in Australia, particularly in certain jurisdictions

In addition to this framework, each strategy provides principles and objectives that determine actions to manage waste within each jurisdiction. Comparisons between these strategies can reveal the inconsistencies that exist between the approaches taken in different jurisdictions. It also provides the opportunity to improve the actions and strategies being advised, according to successful outcomes in jurisdictions that have led by example. In order to keep the review relevant to the context of C\&D waste, only strategies that have directly or indirectly impacted on C\&D waste management activities are described.

Table 3. Regulatory framework (key documents) to guide energy recovery activities in different jurisdictions

\begin{tabular}{|c|c|c|}
\hline & Document(s) & C\&D waste \\
\hline ACT & 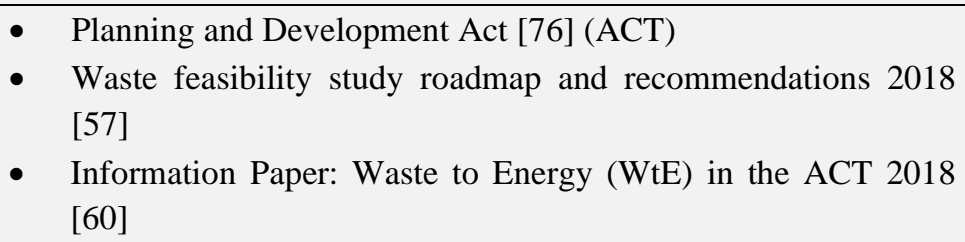 & $\begin{array}{l}\text { No specific information } \\
\text { about C\&D EfW }\end{array}$ \\
\hline NSW & $\begin{array}{l}\text { - } \quad \text { NSW Energy from Waste Policy Statement [77] (NSW) } \\
\text { - } \quad \text { Protection of the Environment Operations Act [78] (NSW) }\end{array}$ & $\begin{array}{l}\text { Specific information for } \\
\text { C\&D waste is provided }\end{array}$ \\
\hline NT & - No specific document & $\begin{array}{l}\text { No specific information } \\
\text { about C\&D EfW }\end{array}$ \\
\hline Qld & $\begin{array}{l}\text { - Waste-Everyone's responsibility Queensland Waste Avoidance } \\
\text { and Resource Productivity Strategy [79] (Qld) } \\
\text { - Transforming Queensland's' Recycling and Waste Industry } \\
2017\end{array}$ & $\begin{array}{l}\text { No specific information } \\
\text { about C\&D EfW }\end{array}$ \\
\hline SA & $\begin{array}{l}\text { - Enhancing resource recovery and discussing the place of energy } \\
\text { recovery } 2018\end{array}$ & $\begin{array}{l}\text { No specific information } \\
\text { about C\&D EfW }\end{array}$ \\
\hline Tas & $\begin{array}{l}\text { - Environmental Management and Pollution Control (Waste } \\
\text { Management) Regulations [80] (Tas) } \\
\text { - No specific document }\end{array}$ & $\begin{array}{l}\text { No specific information } \\
\text { about C\&D EfW }\end{array}$ \\
\hline Vic & $\begin{array}{ll}\text { - } & \text { Environment Protection Act [16] (Vic) } \\
\text { - } & \text { Getting Full Value Policy [81] (Vic) } \\
\text { - } & \text { Environment Protection (Scheduled Premises) Regulations [82] } \\
& \text { (Vic) } \\
\text { - } & \text { Statewide waste and resource recovery infrastructure plan: A } 30 \\
& \text { year roadmap for Victoria [83] (Vic) } \\
\text { - } & \text { EPA's Energy from Waste Guidelines 2013/2017 }\end{array}$ & $\begin{array}{l}\text { No specific information } \\
\text { about C\&D EfW }\end{array}$ \\
\hline WA & - Waste to Energy Position Statement [84] (WA) & $\begin{array}{l}\text { No specific information } \\
\text { about C\&D EfW }\end{array}$ \\
\hline
\end{tabular}


In the ACT's waste strategy document [75], it is estimated that, as of 2010, new EfW technologies are able to produce power for about $6 \%$ of the ACT's needs. The ACT is considering the development of a new market for energy recovered from C \& D waste. On this basis, in 2009, the ACT government commissioned URS-Eco Waste to provide a list of potential materials for the development of a market for EfW. According to their findings, the ACT can use $10-20 \%$ of volume constituted by all waste streams for EfW. The waste strategy document proposes one strategy for EfW activities: Strategy 4.3 (Expand bioenergy generation and investigate new energy-from-waste technologies to generate energy).

The ACT government does not have a specific guideline for EfW and the proposals for energy recovery projects are regulated under the Planning and Development Act [76]. The ACT is working to produce an EfW policy in winter 2019. In doing so, some suggestions will be provided; these include consideration of feed-in tariffs and carbon price mechanisms [57]. Furthermore, it is advised that the "community support and "buy-in" initiative" are critical factors for successful development of EfW policy [60].

In NSW, a policy statement describes the requirements for waste energy recovery for general waste [85]. This policy covers thermal EfW technology, sets out resource recovery criteria and provides a list of eligible (low-risk) waste fuels. According to this document, the percentage of residual waste allowed for energy recovery of $C \& D$ waste material is only up to $25 \%$ of the waste stream received at the processing facility. Although the policy presents regulatory certainty to industry through setting the minimum requirements for establishment of EfW facilities, there is evidence provided by the Hunter Joint Organisation of Councils that current the Waste to Energy Policy presents barrier to the development of EfW facilities [56]. In the Protection of the Environment Operations Act [78] (NSW), the definition of energy recovery refers to two categories: 1) from general waste and 2) from hazardous and other waste. The Act recognises an energy recovery practice when there is recovery of more than 200 tonnes of waste.

In the NT, there is no specific policy or plan to guide activities on energy recovery.

In Qld, a strategy document [86] revealed the opportunities in the state's waste management, including new technologies to take advantage of energy recovery activities. Under this opportunity, the need for development of specific policy is emphasised. Interestingly, Qld has released a Direction Paper [87] that considers energy captured from landfill gas and incineration material loss. This is in contradiction with the End of Waste framework premises, in which there is a baseline determining when a waste is not waste anymore and becomes a source. However, this state is exploring the potential of EfW, which is meant to develop a policy to promote the safe and sustainable delivery of waste-to-energy. Along these lines, the state government has committed to funding of $\$ 5$ million for EfW projects for its 2018-2019 budgets, sourced from the landfill levy revenue [88].

SA is a pioneer in implementing EfW practices, beginning in February 2010 when the first Australian Standard for the production and use of Refuse Derived Fuel [89] (RDF) was released. These standards, which are aligned with the objectives of the primary waste related act [14] and the Environmental Protection (Waste to Resources Policy 2010), outlines a risk-based approach to address the issues and considerations of producing and using RDF.

In SA, the EPA has initiated efforts to develop policy guidance for EfW facilities. A document [69] published as a result provides advice on how to grow this industry in the state. In 2018, the EPA SA invited the relevant stakeholders to comment on the considerations regarding the establishment of EfW position statement. SA's Waste Strategy document (2015-2022) [90] indicates the issue of residual waste in SA and provided advisory support for adopting new technologies and processes to effectively manage residual waste streams.

In Tas, while a specific guideline on EfW is yet to be developed, in the Environmental Management and Pollution Control (Waste Management) 
Regulations [80] (Tas), energy from waste is considered as a waste management method. Furthermore, there have been some unsuccessful discussions about using wood waste to generate power at the state level [91]. Efforts were put into the revision of the Tasmanian Renewable Energy Target (RET) to include waste wood. In 2017, a Local Government Association Tasmania report on waste management [92] identified the need to establish and EfW policy and guidelines; however, this action is proposed as low priority for the long term.

In Vic, the state government recognises that EfW has the potential to play an increasing role in the future waste management of the state. The primary legislation, the Environment Protection Act [16], determines the duties of Victoria's Environmental Protection Authority to facilitate increased environmental resource use efficiency or decreased disposal of waste off-site. It requires persons who undertake certain activities that impact on the environment or any segment of the environment-as a result of high and potentially inefficient use of environmental resources (including water and energy) or disposal of waste off-site-to make an assessment of opportunities to improve environmental resource use efficiency and to reduce the disposal of waste off-site. It also requires such individuals to develop and implement an Environment and Resource Efficiency Plan, which includes financially viable actions to improve environmental resource use efficiency and reduce the disposal of waste off-site; and report on environmental resource use and the disposal of waste off-site and implementation of Environment and Resource Efficiency Plans. Under Part I of this act, there are number of principles in management of environment in Victoria, of which 11 are used to assess energy recovery proposals across the states. These principles are: waste hierarchy, integrated environmental management, integration of economic, social and environmental considerations, improved valuation, pricing and incentive mechanisms, and product stewardship.

This EPA produced act supports the Metropolitan Waste Management group, whose objectives focus on maximising the sustainable recovery of materials from waste for reuse, recycling, reprocessing and energy recovery. Under this Act, the Metropolitan Plan (metropolitan Melbourne) must include a strategic analysis of existing infrastructure and services for waste management and resource recovery of materials and energy ( $\mathrm{p}$. 264). However, Sustainability Victoria, which was founded under the Sustainability Victoria Act 2005, is responsible for coordination of efforts towards resource efficiency and renewable energy, but does not provide enough information and plans regarding EfW. The Environment Protection (Scheduled Premises) Regulations [82] is another set of regulations that govern EfW activities; it presents the exemption requirements for financial assurance and works approval.

In 2000, Vic EPA published an information bulletin [93] on the options available for landfill site owners to manage waste, including energy recovery (capture) from methane gas generated. Victoria's State Waste and Resource Recovery Infrastructure Plan (SWRRIP) [83] also emphasises energy recovery when it does not remove the opportunity for recycling. The plan advises that there is a need for investment in infrastructure, securing long-term feedstock supply and market for energy generated, and the development of a business case that is competitive with the landfill levy. SWRRIP also provide a categorisation model for different infrastructure, including an EfW facility. In 2017, the EPA produced a guideline, Energy from Waste [94], to display how the legislation in Vic is applied to the assessment of proposals that recover energy from waste. The scope of this guideline is to establish a connection between the new EfW technology likely to emerge in the Victorian market and corresponding regulatory updating. This guideline also encourages applicants to engage community from the initial stage of construction of the EfW facility. It provides information about thermal efficiency, sitting, design, construction and preparation of energy recovery facilities and requirements for waste acceptance and preparation for EfW. 
Three statutory documents primarily govern any proposal related to EfW: the Environment Protection Act 1970, the Energy from Waste Guidelines and the Getting Full Value Policy. EPA takes the primary Act's 11 principles mentioned above into consideration when assessing EfW facility establishment and operation. The Energy from Waste Guideline also provides four key criteria for assessing proposals: (1) suitability of EfW as an option, (2) waste acceptance and preparation for energy recovery, (3) sitting, design, construction and operation of EfW facilities, and (4) thermal efficiently of EfW plants. The guideline leaves the responsibility of demonstrating that EfW is the best waste management option to applicants. This can be done through conducting a cost-benefit analysis of different options. The other set of principles are outlined in the Getting Full Value policy [95].

In 2018, the state government undertook a consultative process to examine how the EfW option can best provide opportunities for statewide and regional economies. Furthermore, a feasible study in Vic [32] revealed that a significant cost disparity between the landfill levy and EfW activities gate fee exists that impedes development of EfW activities in this state. The consultees of this study also indicated that lack of support from landfill levy redistribution is another major barrier. The study found that EPA Vic, as the main regulator of EfW, should take the following steps in order to better manage energy recovery activities:

- Provide clear guidance to the market for energy recovery products

- Establish genuine engagement between the regulator and the sector on the critical approvals processes, including planning and works approvals, and land acquisition of suitably zoned sites

- Work proactively with the industry to identify beneficial reuse options for waste to energy byproducts through market development funding for research and reuse opportunities

Lastly, local government launched a community consultation opportunity (Turning waste into energy) to seek feedback from community, industry and other stakeholders about EfW.
In WA, there is not much support for energy recovery practices. The only relevant benefit espoused regarding waste related regulations is the exemption provided for the waste that is received at landfill for collecting and sorting purposes and will later be used for energy recovery. This exemption, enshrined in the Waste Avoidance and Resource Recovery Levy Regulation [12] (WA), exempted landfill owners, by application, from paying the levy. In the waste strategy of this state, a target has been set to make sure that energy recovery practices are only applied to residual waste by 2020 ; this limitation reflects a commitment to following the most favourable options in the waste hierarchy. WA also released an EfW position statement in 2013 that contained general information about energy recovery potential in the state. It also recognised the need for significant developments in policies, regulations and technologies. In the same year, WSP Environmental Co was tasked with conducting a literature review on the regulatory framework, available technologies and other matters related to EfW. At the conclusion of those tasks, some recommendations were made to the WA's Minister of Environment to consider developing the EfW industry in the state [96].

\subsection{Technological inadequacies}

While the technology for energy recovery has been around for decades and has been thoroughly roadtested in certain parts of the world (e.g. Europe and Asia) it is still at an early stage of development in Australia. There are very few instances of EfW facilities presently in operation within Australia (Table 1). Traditionally, the main current technology used in Australia is landfill gas collection and energy recovery [69]. The existing facilities, however, have limited acceptance of waste and barely use residual C\&D waste. Certain jurisdictions (i.e. Qld, NSW, Vic, WA and SA) have undertaken some form of investigation into the potential for EfW industry development. The focus of these investigations has mainly been on thermal technologies. In 2013, the WA Authority commissioned ESP Environmental to review the state-of-the-art EfW technologies [97]. This study 
presented 15 case studies from around the globe that have successfully achieved EfW.

\section{Conclusion}

\subsection{Energy recovery in Australia: opportunities and challenges}

EfW is the second to the last preferred method of waste management in Australia and elsewhere. However, with recent advances in related technologies [97], an increase in public environmental and social awareness [32] and other external factors (e.g. China's ban on import of waste) [98] more attention in being drawn from environmental agencies and decision makers towards its role in the waste management system [56]. In Australia, as a new method, EfW is still a contentious topic that raises differing perceptions toward its adaptation. This is reflected in the negligible share of EfW (4\%) in the current waste management system. However, as outlined above, there is certainly room to improve in this area. In order to improve EfW status in Australia, a number of steps have to be taken to ensure that EfW becomes a viable waste management option that is socially accepted and environmentally beneficial. These steps are mainly related to the state and federal government's role in regulation and supporting EfW technologies. Some of the steps revealed by the review findings are discussed below.

\subsection{Australian government}

The federal government, as one of the main players in the field of EfW, can perform some key measures to ensure improved energy recovery in Australia. These measures include:

(1) Encouraging local governments to support EfW in each state or territory through platforms such as the Australian Local Government Association and National Environment Protection Council;

(2) Developing a harmonised, specific and national policy for EfW, in keeping with social and environmental concerns across Australia;
(3) Providing funding for the establishment of suitable EfW infrastructures;

(4) Commissioning research studies that inform EfW policy and provide an overview of the energy recovery status quo in Australia and other parts of the world;

(5) Stimulating domestic and foreign investment in EfW technologies;

(6) Cultivating interest in EfW in the Australian waste and recycling industry; and

(7) Setting reimbursement incentives that will maintain the economic welfare of residents, such as tax relief or reduction of utility bills.

\subsection{Jurisdictions' role in adopting EfW method}

This review study revealed substantial differences in regulation and adaptation of EfW in different jurisdictions. Among the jurisdictions, only Vic and NSW have published guidelines for EfW; WA released a position statement that has not been upgraded to a clear guideline or policy at time of writing. These inconsistencies are a barrier towards successful implementation of an energy recovery system in Australia. According to the review results, these differences are attributed to various factors that are outlined below. These factors can guide the steps that need to be taken by local governments to improve energy recovery:

(1) Lack of uniform understanding of energy recovery,

(2) Insufficient support or underestimating EfW by some state governments,

(3) Lack of proper infrastructures,

(4) The cost disparity between landfill levy and EfW associated costs,

(5) Lack of programs to educate the wider community,

(6) Lack of regulatory support from the EPAs and other relevant agencies

(7) Lack of a robust waste data management system in some jurisdictions.

The other assistance required from jurisdictional regulatory frameworks is related to the way that different jurisdictions regard a waste material during different phases of waste management. Currently, except for in Qld, all other 
jurisdictions are subscribed to the idea that "once a waste, always a waste". In Qld, the concept of the end of waste framework was introduced in regulations to determine when waste ceases to be waste and becomes a source. Some other jurisdictions, such as WA, SA and Vic, provide some regulatory exemptions for materials that are to be recovered.

\subsection{Further studies}

Establishing sound policy benefits from evidencebased practices that draw on empirical research studies. This review found that there are some areas that need to be further explored in order to change the EfW status quo. Research is needed on people's acceptance of EfW activities in their neighbourhood. It is also necessary to regularly review the state-of-the-art technologies operating in different countries, which will lead to recommendations for the selection of technologies suitable to the Australian context. Market development research for EfW can provide the basis for further legislation and the making informed decisions. Lastly, empirical research is needed to shed light on the potential of residual C \& D waste energy recovery in Australia. Currently, there are only research studies published on EfW on other waste streams and materials, such as food waste [99, 100], wood waste [91] and oil [101].

\section{Acknowledgement}

The authors would like to acknowledge the support of the Australia Sustainable Built Environment National Research Centre (SBEnrc), Project 1.65. However, the views expressed in this article are those of the authors and do not necessarily represent the views of SBEnrc.

\section{References}

[1] ABS 2006. Australian and New Zealand Standard Industrial Classification In: STATISTICS, A. B. O. (ed.). ABS.

[2] Trading Economics 2018. Australia GDP from Construction. Trading Economics

[3] NWR 2018. Australian National Waste Report 2018. Department of the Environment and Energy.
[4] Udawatta N, Zuo J, Chiveralls K, Zillante G (2015). Attitudinal and behavioural approaches to improving waste management on construction projects in Australia: benefits and limitations, International Journal of Construction Management, 15, 137-147.

[5] London K, Siva J, Zhang P (2013). A supply chain management self-assessment framework for waste minimization for the residential sector. Report, RMIT University

[6] Zero Waste 2007. Low Cost Zero Waste Municipality. Available at: http://www.medzerowaste.eu/zerowaste.html. [Accessed: 19 March 2019].

[7] Epa Victoria 2004. Waste Management Policy (Siting, Design and Management Of Landfills). Available at: https://www.epa.vic.gov.au/aboutus/legislation/waste-legislation/wastemanagement-policies. [Accessed: 21 July 2019]

[8] Park J, Tucker R (2017). Overcoming barriers to the reuse of construction waste material in Australia: a review of the literature. International Journal of Construction Management, 17, 228-237.

[9] Hyder 2011. Construction and Demolition Waste Status Report: Management of Construction and Demolition Waste in Australia. Australia Department of Energy and Environment (Department of Sustainability, Environment, Water, Population and Communities). Available at: https://www.environment.gov.au/system/files/reso urces/323e8f22-1a8a-4245-a09c-

006644d3bd51/files/construction-waste.pdf

[Accessed: 19 September 2018]

[10] Australia Capital Territory Government. Waste Management and Resource Recovery Act 2016. Available at: https://www.legislation.act.gov.au/ a/2016-51 [Accessed: 19 September 2018]

[11] New South Wales Government. Waste Avoidance and Resources Recovery ACT 2001 NSW. Available at: https://www.legislation.nsw.gov.au/ \#/view/act/2001/58 [Accessed: 19 September 2018].

[12] Western Australia Government. Waste Avoidance and Resource Recovery Levy Regulation 2008 WA. Available at: https://www.der.wa.gov.au/ourwork/legislative-review-regulatory-reforms/301waste-avoidance -and-resource-recovery-levyregulations-2008 [Accessed: 28 April 2019]

[13] Queensland Government. Waste Reduction and Recycling ACT 2011. Available at: https://www.legislation.qld.gov.au/view/html/infor 
ce/current/act-2011-031 [Accessed: 28 April 2019].

[14] Environmental Protection ACT 1993. Waste Reduction and Recycling ACT 2011. Available at: https://www.legislation.qld.gov.au/view/html /inforce/current/act-2011-031 [Accessed: 13 April 2019].

[15] Government of South Australia. Green Industries SA ACT 2004. Available at: https://www.legislation.sa.gov.au/LZ/C/A/ENVIR ONMENT\%20PROTECTION\%20ACT\%201993. aspx [Accessed: 28 April 2019].

[16] Victoria Government. Environment Protection Act 1970. Available at: http://www.legislation. vic.gov.au/Domino/Web_Notes/LDMS/LTObject _Store/LTObjSt2.nsf/DDE300B846EED9C7CA2 57616000A3571/367C2C1E3FA0677FCA257761 001FCB97/\$FILE/70-8056a172.pdf [Accessed: 19 April 2019]

[17] Danish EPA 2017. Waste Statistics 2015. Available at: $\quad$ https://www2.mst.dk/Udgiv/ publications/2017/08/978-87-93614-20-8.pdf. [Accessed: 19 September 2018]

[18] Statistics Norway 2018. 10513: Waste Account for Norway, By Treatment and Material (1 000 tonnes) 2012-2016. Available at: https://www.ssb.no/en/ statbank/table/10513 [Accessed: 22 July 2019].

[19] DEFRA 2018. Official Statistics UK Statistics on Waste. Department for Environment, Food \& Rural Affairs. Available at: https://assets. publishing.service.gov.uk/government/uploads/sys tem/uploads/attachment_data/file/784263/UK_Stat istics_on_Waste_statistical_notice_March_2019_r ev_FINAL.pdf. [Accessed: 19 September 2018].

[20] USEPA 2018. Documentation for Greenhouse Gas Emission and Energy Factors Used in the Waste Reduction Model (WARM). Office of Resource Conservation and Recovery. Available at: https://www.epa.gov/sites/production/files/201603/documents/warm_v14_management_practices. pdf [Accessed: 15 April 2019].

[21] Hendriks ChF, Pietersen H (2000). Sustainable Raw Materials: Construction And Demolition Waste. Cachan Cedex, France: RILEM Publication.

[22] Member States 2015. Resource Efficient Use of Mixed Waste: CDW Factsheet Final. Available at: https://ec.europa.eu/environment/waste/studies/pdf /CDW_Final_Report.pdf [Accessed: 11 March 2019]
[23] Zhou H., Meng A, Long Y, Li Q, Zhang Y (2014). Classification and comparison of municipal solid waste based on thermochemical characteristics. Journal of the Air \& Waste Management Association, 64, 597-616.

[24] Wolsink M (1994). Entanglement of interests and motives: assumptions behind the NIMBY-theory on facility siting. Urban Studies, 31, 851-866.

[25] Lober, DJ, Green DP (1994). NIMBY or NIABY: A logit model of opposition to solid-waste-disposal facility siting. Journal of Environmental Management, 40, 33-50.

[26] Li W, Liu J, Li D (2012). Getting their voices heard: Three cases of public participation in environmental protection in China. Journal of Environmental Management, 98, 65-72.

[27] Kikuchi R, Gerardo R (2009). More than a decade of conflict between hazardous waste management and public resistance: A case study of NIMBY syndrome in Souselas (Portugal). Journal of Hazardous Materials, 172, 1681-1685.

[28] Huang Y, Ning Y, Zhang T, Fei Y (2015). Public acceptance of waste incineration power plants in China: Comparative case studies. Habitat International, 47, 11-19.

[29] Ren X, Che Y, Yang K, Tao Y (2016). Risk perception and public acceptance toward a highly protested Waste-to-Energy facility. Waste Management, 48, 528-539.

[30] Nielsen 2014. CPIA Waste-to-Energy Summary Report, Canada.

[31] Achillas C, Vlachokostas C, Moussiopoulos N, Banias G, Kafetzopoulos G, Karagiannidis A (2011). Social acceptance for the development of a waste-to-energy plant in an urban area. Resources, Conservation and Recycling, 55, 857-863.

[32] Genever M (2017). Report to the Minister for Energy, Environment and Climate Change: Waste to energy consultation and case study for Melbourne's West. Melbourne: Parliament of Victoria. Available at: http://www.cesarmelhem. com.au/wp-content/uploads/2018/02/RI032-01R01-Waste-to-energy-consultation-Report-2602 2018.pdf [Accessed: 5 May 2019]

[33] Baxter J, Ho Y, Rollins Y, Maclaren V (2016). Attitudes toward waste to energy facilities and impacts on diversion in Ontario, Canada. Waste Management, 50, 75-85.

[34] Miranda ML, Hale B, (1997). Waste not, want not: the private and social costs of waste-to-energy production. Energy Policy, 25, 587-600. 
[35] Vollebergh H (1997). Environmental externalities and social optimality in biomass markets: waste-toenergy in The Netherlands and biofuels in France. Energy Policy, 25, 605-621.

[36] Jamasb T, Nepal R (2010). Issues and options in waste management: a social cost-benefit analysis of waste-to-energy in the UK. Resources, Conservation and Recycling, 54, 1341-1352.

[37] Porter RC. The Economics of Waste, 2010, Routledge.

[38] Dijkgraaf E, Vollebergh HR (2004). Burn or bury? A social cost comparison of final waste disposal methods. Ecological Economics, 50, 233-247.

[39] Cucchiella F, D'adamo I, Gastaldi M (2017). Sustainable waste management: Waste to energy plant as an alternative to landfill. Energy Conversion and Management, 131, 18-31.

[40] Johnson $\mathrm{T}$ (2013). The health factor in anti-waste incinerator campaigns in Beijing and Guangzhou. The China Quarterly, 214, 356-375.

[41] Funk K, Milford J, Simpkins T (2013). Waste Not, Want Not: Analyzing the Economic and Environmental Viability of Waste-to-Energy (WTE) Technology for Site-Specific Optimization of Renewable Energy Options. National Renewable Energy Lab.(NREL), Golden, CO (United States). Available at: https://www.nrel.gov /docs/fy13osti/52829.pdf [Accessed: 19 September 2018].

[42] Luoranen M, Horttanainen M (2008). Cogeneration based energy recovery from municipal solid waste integrated with the existing energy supply system. Waste Management, 28, 30-38.

[43] Yano J, Sakai SI (2016). Energy recovery and greenhouse gas reduction potential from food waste in Japan. Journal of Material Cycles and Waste Management, 18, 631-645.

[44] WRAP 2012. EfW development guidance. Waste \& Resources Action Programme. Available at: http://www.wrap.org.uk/sites/files/wrap/O_And_E FW_Guidance_FULL.pdf [Accessed: 5 May 2019]

[45] National Waste Policy 2018. Less Waste. More Resources. The Australian Government. Available at: https://www.environment.gov.au /system/files/resources/d523f4e9-d958-466b-9f d1-3b7d6283f006/files/national-waste-policy2018.pdf [Accessed: 13 April 2019]

[46] Wang J, Wu H, Tam VW, Zuo J (2019). Considering life-cycle environmental impacts and society's willingness for optimizing construction and demolition waste management fee: An empirical study of China. Journal of Cleaner Production, 206, 1004-1014.

[47] Stahel WR (2016). The circular economy. Nature News. Available at: https://www.nature.com/ news/the-circular-economy-1.19594 [Accessed: 12 March 2019]

[48] Waste Authority. 2018. Waste Strategy 2030. Available at: http://www.wasteauthority.wa.gov. au/about/waste-strategy/ [Accessed: 10 December 2018]

[49] Esa MR, Halog A, Rigamonti L (2017). Developing strategies for managing construction and demolition wastes in Malaysia based on the concept of circular economy. Journal of Material Cycles and Waste Management, 19, 1144-1154.

[50] Annual report on the Environment, the Sound Material-Cycle Society and Biodiversity in Japan. Ministry of The Environment 2016.

[51] IBISWORLD 2019. Construction in Australia. IBISWorld.

[52] Wainberg R (2012). The State of Waste. Waste Management Association of Australia

[53] Australian Bureau of Statistics. Australian Demographic Statistics. Available at: https:// www.abs.gov.au/ausstats/abs@.nsf/mf/3101.0 [Accessed: 14 June 2019]

[54] Martek I, Hosseini MR, Shrestha A, Edwards DJ, Durdyev S (2019). Barriers inhibiting the transition to sustainability within the Australian construction industry: An investigation of technical and social interactions. Journal of Cleaner Production, 211, 281-292.

[55] Australian Bureau of Statistics. Engineering Construction Activity, Australia. Available at: https://www.abs.gov.au/ausstats/abs@.nsf/mf/876 2.0 [Accessed: 18 June 2019]

[56] Environment and Communications References Committee 2018. Never waste a crisis: the waste and recycling industry in Australia. Available at: https://www.aph.gov.au/Parliamentary_Business/ Committees/Senate/Environment_and_Communic ations/WasteandRecycling/Report [Accessed: 07 December 2018].

[57] ACT NOWASTE 2018. Waste Feasibility Study Roadmap and Recommendations. Available at: https://s3.ap-southeast-2.amazonaws.com/hdp. au.prod.app.act-yoursay.files/1115/3861/9020/ WFS_Roadmap_consultation_report.pdf [Accessed: 07 April 2019]

[58] ACT NOWASTE 2018. Waste Feasibility Study Roadmap: Consultation Report. Available at: 
https://s3.ap-southeast-2.amazonaws.com/hdp. au.prod.app.act-yoursay.files/1115/3861/9020/

WFS_Roadmap_consultation_report.pdf [Accessed: 07 April 2019]

[59] EPA VIC 2018. A review of the scientific literature on potential health effects in local communities associated with air emissions from Waste to Energy facilities. Melbourne Environmental Protection Authority Victoria. Available at: https://www.epa.vic.gov.au/ /

media/Publications/1718.pdf [Accessed: 04

October 2018]

[60] Transport Canberra and City Services Directorate. Information Paper waste-to-energy (WtE) in the ACT. Available at: https://s3.ap-southeast2.amazonaws.com/hdp.au.prod.app.act yoursay.files/5815/3861/5790/Waste-to-energy _information_paper_final.pdf [Accessed: 23 May 2019]

[61] Frydenberg J. (2017). Turning waste into fuel. Department of the Environment and Energy

[62] City of Darwin, Renewable Energy Facility (2018). Available:https://www.darwin.nt.gov.au/live/wast e-recycling/shoal-bay-waste-managementfacility/renewable-energy-facility [Accessed date].

[63] Waste Management Review 2018. REMONDIS intends to develop \$400M QLD waste to energy facility. Waste Management Review. Available at: $\mathrm{http}: / /$ wastemanagementreview.com.au/ remondisintends-develop-400m-qld-waste-energy-facility/

[Accessed: 10 December 2018]

[64] Fromberg, A. 2015. Native wood waste hoped to fire up Tasmanian energy industry as environmentalists oppose biomass as renewable energy. ABS News. Available at: https://www.abc.net.au/news/2015-07-19/ tasmanian-forest-industry-fired-up-aboutbiomass/6628822. [Accessed: 02 March 2019]

[65] Sustainability Victoria 2019. Waste to energy infrastructure fund. Available at: https://www.sustainability.vic.gov.au/Grants-andfunding/Waste-to-energy-infrastructure-fund. [Accessed: 11 December 2018]

[66] Waste Authority 2017. Western Australian Waste Avoidance and Resource Recovery Strategy: Consultation paper. Available at: https:// www.wasteauthority.wa.gov.au/media/files/docum ents/Strategy_review_discussion_paper.pdf [Accessed: 09 December 2018]

[67] Renew Economy, Australian-first" big waste-toenergy plant reaches financial close in W.A (2018).
Available:https://reneweconomy.com.au/australian -first-big-waste-to-energy-plant-reaches-financialclose-in-w-a-59064/ [Accessed: 09 December 2018].

[68] Department of The Environment and Energy. State and Territory Greenhouse Gas Inventories 2015Australia's National Greenhouse Accounts. Available at: http://www.environment. gov.au/climate-change/climate-science-data/ greenhouse-gas-measurement/publications [Accessed: 19 May 2019]

[69] EPA SA 2018. Enhancing Resource Recovery and Discussing the Place of Energy Recovery: Reforming Waste Management- Creating Certainty for an Industry to Grow. Available at: https://www.epa.sa.gov.au/environmental_info/wa ste_management/reforming-waste-manage ment2015 [Accessed: 16 September 2018]

[70] Australian Government. National Environment Protection Council Act 1994 Cth. Canberra. Available at: https://www.legislation.gov.au/ Details/C2016C00844. [Accessed: 10 October 2018]

[71] Australian Government. Renewable Energy (Electricity) Act 2000. Available at: https://www.legislation.gov.au/Details/C2019C00 061 [Accessed: 12 May 2019].

[72] Australian Government. National Environment Protection Council(Ambient Air Quality) Measure. Available at: https://www.legislation.gov.au/ Series/F2007B01121. [Accessed: 13 December 2018]

[73] Australian Government. National Environment Protection Council (Air Toxics) Measure. Available at: https://www.legislation.gov.au/ Series/F2007B01121. [Accessed: 13 December 2018]

[74] Australian Government. Environment Protection and Biodiversity Conservation ACT 1999. Available at: https://www.legislation.gov.au/ Details/C2016C00844. (Accessed: 10 October 2018).

[75] Environment and Sustainable Development Directorate ACT waste management strategy: towards a sustainable Canberra : reducing waste and recovering resources to achieve a sustainable, carbon-neutral Canberra 2011-2025/ACT Government Environment and Sustainable Development, 2011.

[76] Australia Capital Territory Government. Planning and Development Act 2007. Available at: 
https://www.legislation.act.gov.au/a/2007-24/

[Accessed: 11 March 2019]

[77] New South Wales EPA. NSW Energy from Waste Policy Statement. Available at: https://www.epa.nsw.gov.au//media/epa/corporate -site/resources/epa/150011enfromwasteps.pdf [Accessed: 18 February 2019]

[78] Department of Environment and Science. Queensland Waste Avoidance and Resource Productivity Strategy 2014-2024 Final review report Available at: https://www.qld.gov.au/ __data/assets/pdf_file/0021/94062/qld-wasteavoid-resource-prod-strat-2014-24.pdf [Accessed: 22 February 2019]

[79] Queensland Government. Waste Management and Resource Recovery Strategy Available at: https://www.qld.gov.au/_data/assets/pdf_file/002 8/103798/qld-waste-management-resourcerecovery-strategy.pdf [Accessed: 21 February 2019]

[80] New South Wales Government. Protection of the Environment Operations Act 1997 No 156 Available at: https://www.legislation.nsw.gov.au /\#/view/act/1997/156 [Accessed: 22 February 2019]

[81] Department of Environment and Primary Industries. Getting full value: the Victorian waste and resource recovery policy, 2013, Victoria Government.

[82] Victoria EPA. Environment Protection (Scheduled Premises) Regulations 2017. Available at: http://www.legislation.vic.gov.au/

Domino/Web_Notes/LDMS/PubStatbook.nsf/93e b987ebadd283dca256e92000e4069/C6F01585296 317ADCA25813F001E0CC5/\$FILE/17-

045sra\%20authorised.pdf [Accessed: 08 February 2019]

[83] Sustainability Victoria 2018. Statewide Waste and Resource Recovery Infrastructure Plan Victoria 2018. Available at: https:// www.sustainability.vic.gov.au/About-us/Whatwe-do/Strategy-and-planning/Statewide-Wasteand-Resource-Recovery-Infrastructure-Plan [Accessed: 11 February 2018].

[84] Waste to Energy Position Statement. 2013, WA, Waste Authority.

[85] New South Wales EPA. NSW Energy from Waste Policy Statement. Available at: https://www.epa.nsw.gov.au//media/epa/corporate -site/resources/epa/150011enfromwastep

[Accessed: 11 February 2018]
[86] Queensland Government 2014. Waste-Everyone's responsibility; Queensland Waste Avoidance and Resource Productivity Strategy (2014-2024). Available at: https://www.qld.gov.au/_data/ assets/pdf_file/0021/94062/qld-waste-avoidresource-prod-strat-2014-24.pdf [Accessed: 03 December 2018]

[87] Queensland Government 2018. Transforming Queensland's Recycling and Waste Industry; Directions Paper. Available at: https://www.qld.gov.au/_data/assets/pdf_file/002 1/69060/transforming-qlds-recycling-wasteindustry-directions-paper.pdf [Accessed: 17 June 2019]

[88] Queensland Government. Renewable Energy. Available at: https://budget.qld.gov.au/ highlights/\#protecting-the-great-barrier-reef

[Accessed: 29 September 2018]

[89] South Australia EPA. Standard for the production and use of refuse derived fuel. Available at: https://www.epa.sa.gov.au/environmental_info/wa ste_management/solid_waste/refuse_derived_fuel [Accessed: 12 September 2018]

[90] Green Industries SA 2015. South Australia's Waste Strategy: 2015-2020.

[91] Rothe A, Moroni M, Neyland M, Wilnhammer M (2015). Current and potential use of forest biomass for energy in Tasmania. Biomass and Bioenergy, 80, 162-172.

[92] MRA Consulting Group. 2017. LGAT Waste and Resource Management Strategy. Available at: https://www.lgat.tas.gov.au/webdata/resources/file s/LGAT\%20Waste\%20and\%20Resource\%20Man agement\%20Strategy_Final\%20.pdf [Accessed: 03 May 2019]

[93] Victoria EPA. Guidelines for Reducing Greenhouse Gas Emissions from Landfills and Wastewater Treatment Facilities. Available at: https://www.epa.vic.gov.au/ /media/Publications/ 968.pdf [Accessed: 25 September 2018]

[94] EPA VIC 2017. Guideline: Energy from waste. Melbourne. Available at: https://www.epa.vic. gov.au/ /media/Publications/1559\%201.pdf.

[Accessed: 02 October 2018]

[95] Getting full value: the Victorian waste and resource recovery policy, Department of Environment, Land, Water and Planning, 2013, Victorian Government

[96] WSP Environmental 2013a. An Investigation into the Performance (Environmental and Health) of Waste to Energy Technologies Internationally. 
Western Australia Department of Environment and Conservation. Available at: https://www. wasteauthority.wa.gov.au/media/files/documents/ W2E_Technical_Report_Stage_One_2013.pdf. [Accessed: 03 October 2018]

[97] WSP Environmental 2013b. Review of State-ofthe-Art Waste-to-Energy Technologies Perth: Department of Environment and Conservation. Available at: http://www.wasteauthority.wa.gov. au/media/files/documents/SWIP_Waste_to_Energ y_Review.pdf. [Accessed: 11 March 2019]

[98] Downes J, Dominish E (2018). China's recycling 'ban' throws Australia into a very messy waste crisis. The Conversation. Available at: https://theconversation.com/chinas-recycling-banthrows-australia-into-a-very-messy-waste-crisis95522 [Accessed: 19 February 2019]

[99] Lou XF, Nair J, Ho G (2013). Potential for energy generation from anaerobic digestion of food waste in Australia. Waste Management \& Research, 31, 283-294.

[100] Florin N, Maddocks A, Wood S, Harris A (2009). High-temperature thermal destruction of poultry derived wastes for energy recovery in Australia. Waste Management, 29, 1399-1408.

[101] El-Hanandeh A (2015). Energy recovery alternatives for the sustainable management of olive oil industry waste in Australia: life cycle assessment. Journal of Cleaner Production, 91, 7888.

[102] Shooshtarian S, Maqsood T, Khalfan M, Wong P, Yang R (2019). Managing construction and demolition (C\&D) waste in Australia. CIB World Building Congress 'Constructing Smart Cities', 1721 June 2019. Hong Kong, China. 